\title{
PCR e-Course: reshaping education in exceptional circumstances
}

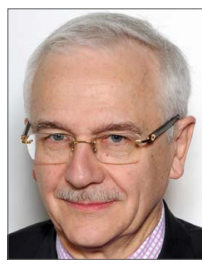

Salvatore Brugaletta, Editor-in-Chief PCR online;

Davide Capodanno, Editor-in-Chief EuroIntervention; Jean Fajadet, Vice-Chairman of PCR;

William Wijns, Chairman of $P C R$

Dear colleagues, dear companions,

We are living through an exceptional moment in world history we certainly don't need to tell you again what we have all heard and are all experiencing. Still, we can offer you what we know best: our support as companions and, most importantly, our contribution as the architects of the PCR Family of Continuing Medical Education.

This has been our goal in creating the 2020 PCR e-Course: to renew our commitment to be present for our community as a whole, in the PCR tradition of sharing knowledge and clinical experience.

We know we are not alone in cancelling our physical meeting, not alone in offering online some key elements of what would have been our physical Course, but there is more. In creating the PCR e-Course, we want to acknowledge that even in these moments of crisis there is a necessary time of reconstruction, a time when we step back from the everyday to gather up our resources.

This edition of EuroIntervention is coming out during the new PCR e-Course, allowing us to take this opportunity to outline briefly what we are trying to achieve and what we hope to accomplish with your participation.

\section{An immersive, virtual learning powerhouse}

Each of the three days of the PCR e-Course will take place online on 5 specially designed channels which will replace - virtually - the different amphitheatres and symposium halls of the physical Course. The "Main Arena" channel will offer real-time moderation with question and answer sessions. This will be an excellent "address" to examine trends as well as explore strategic and long-term thinking on a few major topics and areas of interest (https://www.pcronline. com/Courses/PCR-e-Course/Programme/Programme-Quick-View). There will be a "Case-Based Learning" channel, allowing for interactive chats, where PCR's practical approach to learning, being attached to the clinical problem of an individual patient, will take place. The "Hotline and Innovation" channel will be specially dedicated to Late Breaking Trials and the latest factual information. There will also be a virtual "corner", a separate online space where you can call up juried Abstracts and Case Reports that you would normally come across in the physical meeting. This will be accompanied by an Abstract Book, a compendium of all submitted abstracts and posters being published online by EuroIntervention. Finally, sponsored symposia will have their own dedicated online space. 
During the PCR e-Course, we will touch on the same themes we would during EuroPCR (fields of interest which are represented in the different sections of EuroIntervention as well): Coronary Interventions, Interventions for Valvular Disease, Peripheral Interventions, Interventions for Hypertension, and Interventions for Stroke. PCR is actually engaging a long-term CME project that will play out during the PCR e-Course and continue over the next two years - a virtual, hands-on, and practical approach to this expanding field of peripheral interventions.

We will also consider ongoing issues related to the impact of COVID-19 on our patients, as we have been doing at PCR online with the "Facing COVID-19 with PCR" project (https://www. pcronline.com/Cases-resources-images/Zoom-on/COVID-19/). This project will be expanded during the PCR e-Course through an update on ongoing antiviral pharmacological trials. Simulationbased learning on improved teamwork will help us in rebuilding our practices and in taking on the treatment of the many nonCOVID patients who have been "left behind".

All of this material will be readily identifiable online, easily accessed and available for review and discussion after the dates of the "live" meeting itself.

Other important initiatives will not be forgotten. Along with our professional association, the EAPCI and the EAPCI Women Committee, the PCR family has committed to facing the challenge of ensuring gender equality. While the planned presentation of a number of dedicated sessions will be postponed, the first "Escalator Award" initiative will be presented online, aiming at maximum outreach to the global interventional community.

This year will also mark the $10^{\text {th }}$ anniversary of the Stent Save a Life initiative. Celebration of the many achievements will be presented on PCR online later this year.

\section{Join us}

How often are we given the opportunity to re-invent ourselves?

We believe that this is such a time - a time when we can build upon the challenges and crisis to construct something new, something good for ourselves and our patients.

Yes, we have our reponsibilities - to our friends, families and colleagues, to our work as doctors and healthcare professionals, to the countries we live in. At the PCR family we have another responsibility - to you, to our community - and it is in this spirit that we dedicate ourselves again to the goals of PCR, that together, "By and For" the Interventional Cardiovascular Community, we can effectively meet the challenges and continue to advance our practice.

The 2020 PCR e-Course is our response today to the practical and philosophical challenges which confront us all ... join us, immerse yourselves, react and exchange ideas and friendship, and together we will succeed. 